\title{
用于超级电容器电极材料的聚苯胺基碳
}

\author{
李利民 ${ }^{1}$ 刘恩辉 ${ }^{1, *}$ 李 剑 1,2 杨艳静 ${ }^{1}$ \\ 沈海杰 1 黄铮铮 ${ }^{1}$ 向晓霞 ${ }^{1}$ \\ ( ${ }^{1}$ 湘潭大学化学学院, 环境友好化学与应用教育部重点实验室, 湖南 湘潭 411105 ; \\ 2 广州市振兴实业有限公司, 广州 510170)
}

\begin{abstract}
摘要：在不同温度下碳化硫酸掺杂的聚苯胺制备了含杂原子(氮和氧原子)的新型碳材料. 分别通过扫描电镜、 元素分析仪、X 射线光电子能谱仪和比表面积测试仪对这些碳材料的形貌特征、元素组成、表面化学组成和比表 面积进行了表征. 用循环伏安法、恒电流充放电法和交流阻抗法对其进行了电化学性能的研究. 研究结果表明, 在温度为 $800{ }^{\circ} \mathrm{C}$ 下碳化聚苯胺得到的碳有很好的电化学性能, 尽管它的比表面积很小 $\left(325 \mathrm{~m}^{2} \cdot \mathrm{g}^{-1}\right)$, 但在 $0.5 \mathrm{~A} \cdot \mathrm{g}^{-1}$ 电流密度下其比电容高达 $153 \mathrm{~F} \cdot \mathrm{g}^{-1}$. 它的高比电容可能与其含有合适比例的杂原子(氮和氧原子)有关, 因为合 适比例的氮和氧杂原子能够产生最大的㕍电容. 这些结果表明这种碳材料是一种很有发展前景的超级电容器电 极材料。
\end{abstract}

关键词：超级电容器; 聚苯胺; 碳; $X$ 射线光电子能谱; 电化学交流阻抗 中图分类号：0646

\section{Polyaniline-Based Carbon for a Supercapacitor Electrode}

\author{
LI Li-Min $^{1} \quad$ LIU En-Hui ${ }^{1, *} \quad$ LI Jian ${ }^{1,2} \quad$ YANG Yan-Jing $^{1} \quad$ SHEN Hai-Jie ${ }^{1}$ \\ HUANG Zheng-Zheng ${ }^{1} \quad$ XIANG Xiao-Xia ${ }^{1}$ \\ $\left({ }^{1}\right.$ Key Laboratory of Environmentally Friendly Chemistry and Applications, Ministry of Education, College of Chemistry, Xiangtan \\ University, Xiangtan 411105, Hunan Province, P. R. China; ${ }^{2}$ Guangzhou Zhenxing Industrial Co., Ltd., \\ Guangzhou 510170, P. R. China)
}

\begin{abstract}
Novel carbon materials containing heteroatoms (nitrogen and oxygen) were prepared by carbonizing $\mathrm{H}_{2} \mathrm{SO}_{4}$ doped polyaniline at different temperatures. The morphology, elemental composition, surface chemical composition, and surface area of the as-prepared samples were investigated by scanning electron microscopy (SEM), elemental analyzer, X-ray photoelectron spectroscopy (XPS) and Brunauer-Emmett-Teller (BET) measurements. Electrochemical properties were studied by cyclic voltammetry $(\mathrm{CV})$, galvanostatic charge/discharge and electrochemical impedance spectroscopy (EIS). The results show that the carbon prepared by carbonizing polyaniline at $800{ }^{\circ} \mathrm{C}$ has good electrochemical performance and its specific capacitance value is as high as $153 \mathrm{~F} \cdot \mathrm{g}^{-1}$ under a current density of $0.5 \mathrm{~A} \cdot \mathrm{g}^{-1}$, although it has a low specific surface area $\left(325 \mathrm{~m}^{2} \cdot \mathrm{g}^{-1}\right)$. The high specific capacitance of this carbon is believed to be due to its proper proportion of heteroatoms (nitrogen and oxygen), which provide a large amount of pseudo-capacitance. This kind of carbon material can thus be used as a promising electrode material in supercapacitors.
\end{abstract}

Key Words: Supercapacitor; Polyaniline; Carbon; X-ray photoelectron spectroscopy; Electrochemical impedance spectroscopy

Received: January 25, 2010; Revised: March 19, 2010; Published on Web: April 30, 2010.

*Corresponding author. Email: liuenhui99@sina.com.cn; Tel: +86-731-58292229.

The project was supported by the Natural Science Foundation of Hunan Province, China (07JJ6015).

湖南省自然科学基金(07JJ6015)资助项目

C Editorial office of Acta Physico-Chimica Sinica 
Supercapacitors have been known over thirty years, which are one of the most promising electrochemical energy storage systems. They have attracted considerable attention since they can provide much higher energy densities than conventional dielectric capacitors, and they can also provide higher power densities and have a longer cycle life than batteries ${ }^{[1-2]}$. Based on different charge storage mechanisms, there have been two major types of supercapacitors including electrical double-layer capacitors (EDLCs) and pseudocapacitors. The capacitance of EDLCs arises from the charge separation at the electrode/electrolyte interface, while the capacitance of pseudocapacitor arises from faradic redox reactions at the electrode/electrolyte surface, for example, transition-metal oxides ${ }^{[3-7]}$ and electroactive polymers ${ }^{[8-11]}$. The noble metal oxides ${ }^{[1,12]}$ and polymers ${ }^{[10,13]}$ as electrode materials have higher specific capacitance than carbon materials, but the cost of noble metal is high and the cycling stability of polymers is short, which limit their application. Carbon materials are thought to be the most attractive electrode materials because of their excellent electrochemical property, high surface area, relatively low cost, and good availability ${ }^{[14]}$.

Various carbon-enriched precursors were used to prepare carbon materials, for example, formaldehyde resin, sucrose, pitch and so on ${ }^{[15-17]}$. However, only several researchers ${ }^{[18-19]}$ used polyaniline as the precursor of carbon materials. They thought the carbon material prepared from polyaniline had low electrical conductivities, and they did not further research the electrochemical properties of the carbon material.

The carbon materials containing heteroatoms (nitrogen and oxygen) by carbonizing polyaniline as electrode materials for supercapacitors were investigated in this article. Because polyaniline is commercially available and very cheap, the preparation process of carbon materials is simple, we believe that it is a promising carbon material for supercapacitors. The elemental composition, surface area and electrochemical characteristics of the samples at different carbonization temperatures were discussed.

\section{Experimental}

\subsection{Preparation of polyaniline}

Aniline (analytical grade) was redistilled before use, deionized water was used in this investigation.

Firstly, $16.8 \mathrm{~mL}$ aniline was injected to $100 \mathrm{~mL} 1 \mathrm{~mol} \cdot \mathrm{L}^{-1}$ $\mathrm{H}_{2} \mathrm{SO}_{4}$ (analytical grade), and $100 \mathrm{~mL} 1 \mathrm{~mol} \cdot \mathrm{L}^{-1}\left(\mathrm{NH}_{4}\right)_{2} \mathrm{~S}_{2} \mathrm{O}_{8}$ (analytical grade) was added drop-wise into the above acid solution containing aniline within $3 \mathrm{~h}$ under constant stirring. The polymerization was continued for $4 \mathrm{~h}$ at room temperature. The solid product was collected, washed with deionized water, and dried at $80{ }^{\circ} \mathrm{C}$ for $48 \mathrm{~h}$ under vacuum condition. The $\mathrm{H}_{2} \mathrm{SO}_{4}$-doped polyaniline was obtained.

\subsection{Preparation of carbon materials}

The polyaniline was carbonized for $2 \mathrm{~h}$ in a tubular furnace (SG2-6-1, Xiangtan Huafeng Co., Ltd., China) under nitrogen atmosphere at 700,800 , and $900{ }^{\circ} \mathrm{C}$, respectively. The heating rate from room temperature was $5{ }^{\circ} \mathrm{C} \cdot \mathrm{min}^{-1}$. The obtained carbons prepared at 700,800 , and $900{ }^{\circ} \mathrm{C}$ were denoted by C700, C800, and $\mathrm{C} 900$, respectively.

\subsection{Materials characterization}

The morphology of the samples was examined using a scanning electron microscope (SEM, Hitachi S5200, Japan). Carbon, hydrogen, nitrogen, and sulphur contents of the samples were determined using a elemental analyzer (CHNS type Vario EL, Elementar Corporation, Germany). Oxygen content was calculated by difference. Before the analysis, all the samples were dried for $1 \mathrm{~h}$ under vacuum condition at $100{ }^{\circ} \mathrm{C}$. The nitrogen adsorption isotherms of the samples at $77 \mathrm{~K}$ were measured by an automatic adsorption instrument (NOVA-2200, Quantachrome Corporation, USA). The specific surface areas and average pore diameters were calculated by Brunauer-Emmett-Teller (BET) equation. The pore size distribution was estimated by BarrettJoyner-Halenda (BJH) method. The surface chemical composition of C800 was characterized by an X-ray Photoelectron Spectrometer (ESCALAB 250, VG Scientific Co., Ltd., UK) with Al $K_{\alpha}$ source. Binding energy calibration was carried out to the main $\mathrm{C}$ $1 s$ peak at $284.6 \mathrm{eV}$. A non-linear, Shirley-type baseline and an iterative least-squares fitting algorithm were used to decompose the peaks, the curves being taken as $80 \%$ Gaussian and $20 \%$ Lorenzian using CASA XPS software.

\subsection{Electrochemical testing}

The electrochemical performances of all carbon samples were investigated using two-electrode Swagelok-type cells without a reference electrode. The electrode was fabricated by pressing a mixture of $80 \%$ (mass fraction, the same below) carbon sample, $10 \%$ acetylene black (Vulcan XC-72, Cabot Corporation, USA), and $10 \%$ polyvinylidene fluoride (PVDF, SCM Industrial Chemical Co., Ltd., China) onto a piece of nickel foil (Changsha Lyrun New Material Co., Ltd., China). Two electrodes with identical or very close masses were selected and then assembled as supercapacitors. The electrolytic solution was $6 \mathrm{~mol} \cdot \mathrm{L}^{-1} \mathrm{KOH}$ (analytical grade). CV were recorded from 0 to $1 \mathrm{~V}$ at various sweep rates, discharge-charge curves were recorded from 0 to 1 $\mathrm{V}$ loading different current densities and EIS measurements were carried out by applying an AC voltage of $5 \mathrm{mV}$ amplitude in the $100 \mathrm{kHz}-10 \mathrm{mHz}$ frequency range using a $\mathrm{CHI} 600 \mathrm{~A}$ electrochemical workstation (CHI Inc., USA). All electrochemical measurements were carried out at room temperature.

The specific capacitance of the electrode is obtained from Eq. (1):

$$
C_{\mathrm{g}}=\frac{I \Delta t}{m \Delta V} \times 2
$$

where $C_{\mathrm{g}}$ is the specific gravimetric capacitance, $I$ is the current loaded, $\Delta t$ is the discharge time, $\Delta V$ is the potential change during the discharge process ( $1 \mathrm{~V}$ in this study), and $m$ represents the mass of electroactive material.

\section{Results and discussion}

\subsection{Characteristics of the carbon samples}



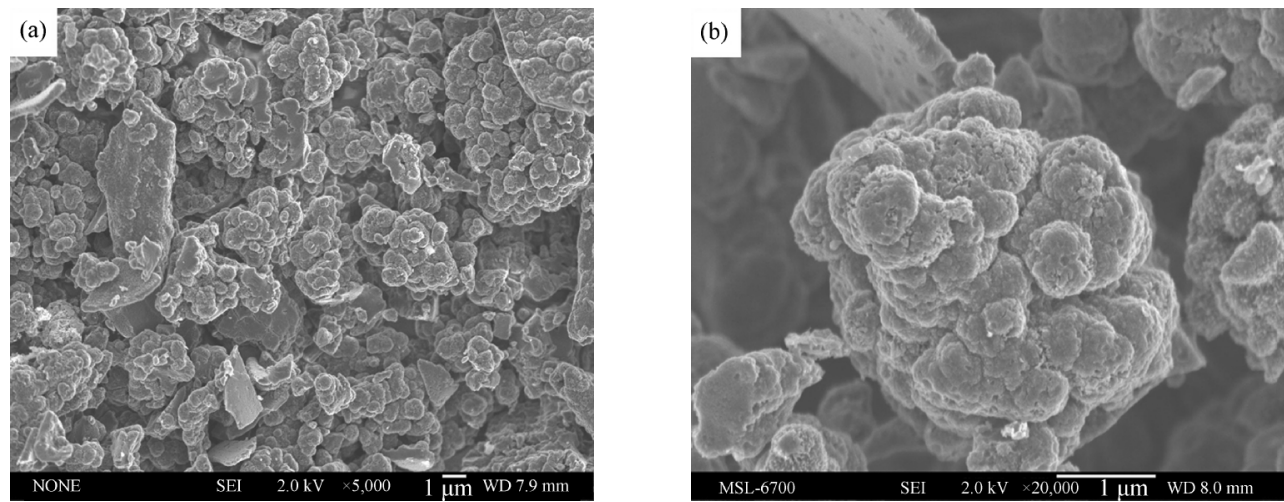

Fig.1 SEM images of polyaniline (a) and C800 (b)

Fig.1(a) depicts representative SEM of polyaniline, it is schistose, and a lot of schistose polyaniline stack together. We found the morphology of carbonized polyaniline (C800) to be practically unchanged (Fig.1(b)).

The $\mathrm{N}_{2}$ adsorption isotherms for the three materials (Fig.2(a)) are type I, indicating that the materials are essentially microporous. Fig.2(b) denotes the pore size distributions of the materials with BJH method. As is shown in Fig.2(b), peaks at pore diameter less than $2 \mathrm{~nm}$ indicate the formation of micropores in the materials.

Table 1 summarizes the textural properties of the samples. C700 has the lowest BET surface area $\left(289 \mathrm{~m}^{2} \cdot \mathrm{g}^{-1}\right)$, and the lowest total pore volume of $0.156 \mathrm{~cm}^{3} \cdot \mathrm{g}^{-1}$, with an average pore diameter of $1.441 \mathrm{~nm}$. On the other hand, C800 has the higher BET surface area $\left(325 \mathrm{~m}^{2} \cdot \mathrm{g}^{-1}\right)$, and the highest total pore volume of $0.184 \mathrm{~cm}^{3} \cdot \mathrm{g}^{-1}$, with an average pore diameter of $1.393 \mathrm{~nm}$. C900 is more similar to C800.

The XPS spectra of C800 (Fig.3) show three distinct peaks, which can be explained by existence of carbon, nitrogen, and oxygen atoms. Fitting of the $\mathrm{C} 1 s$ spectrum can be resolved into four individual component peaks at binding energy of 284.8, 286.3, 287.6, and $289.3 \mathrm{eV}$, representing graphitic carbon, carbon present in alcohol or ether groups, carbonyl groups, and carboxyl or ester groups ${ }^{[20]}$, respectively.

Various oxygen-containing functional groups existing on the carbon surface were also confirmed through XPS measurement.

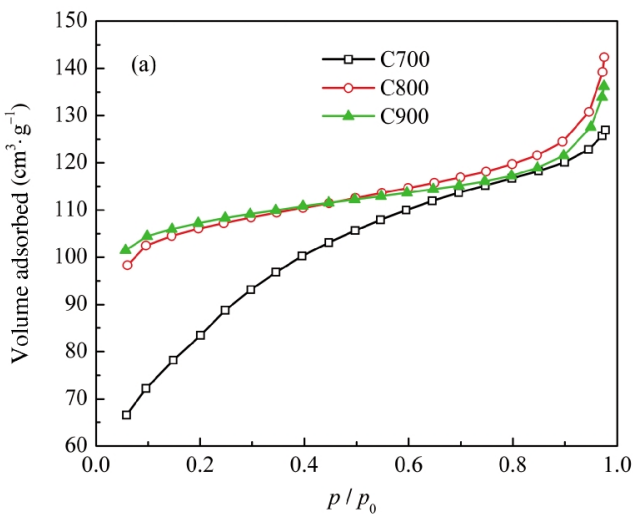

Table 1 Textural characteristics and specific capacitance of C700, C800, and $\mathrm{C} 900$

\begin{tabular}{ccccc}
\hline Sample & $\mathrm{S}_{\mathrm{BET}} /\left(\mathrm{m}^{2} \cdot \mathrm{g}^{-1}\right)$ & $D_{0} / \mathrm{nm}$ & $V /\left(\mathrm{cm}^{3} \cdot \mathrm{g}^{-1}\right)$ & $C_{\mathrm{g}} /\left(\mathrm{F} \cdot \mathrm{g}^{-1}\right)$ \\
\hline C700 & 289 & 1.441 & 0.156 & 110 \\
C800 & 325 & 1.393 & 0.184 & 153 \\
C900 & 327 & 1.391 & 0.175 & 75 \\
\hline
\end{tabular}

$S_{\mathrm{BET}}$ : BET surface area; $D_{0}$ : average pore diameter; $V$ : total pore volume;

$C_{\mathrm{g}}:$ specific gravimetric capacitance at a current density of $0.5 \mathrm{~A} \cdot \mathrm{g}^{-1}$

The oxygen atoms may come from sulfate. O $1 s$ core level spectrum reveals the presence of four peaks, corresponding to $\mathrm{C}=\mathrm{O}$ groups $(530.9 \mathrm{eV})$, carbonyl oxygen atoms in esters, amides, anhydrides and oxygen atoms in hydroxyls or ethers $(532.2 \mathrm{eV})$, the ether oxygen atoms in esters and anhydrides $(533.3 \mathrm{eV})$ and the oxygen atoms in carboxyl groups $(534.5 \mathrm{eV})^{[21-22]}$.

Fitted $\mathrm{N} 1 s$ regions indicate several different species presenting on the carbon surface. Nitrogen exists mainly in four states. Every individual component peak can be ascribed to N-6 (pyridinic nitrogen, $(398.7 \pm 0.3) \mathrm{eV}$ ), N-5 (pyrrolic nitrogen and pyridone nitrogen in association with oxygen functionality, (400.3 \pm $0.3) \mathrm{eV}$ ), N-Q (quaternary nitrogen, nitrogen substituted with carbons in the aromatic grapheme structure, $(401.4 \pm 0.5) \mathrm{eV})$ and $\mathrm{N}$ $\mathrm{X}$ (pyridine N-oxide, 402-405 eV) ) $^{[20,23-25]}$.

\subsection{Electrochemical properties of carbon electrodes}

The CV curves for as-prepared samples at a scan rate of 2 $\mathrm{mV} \cdot \mathrm{s}^{-1}$ are presented in Fig.4(a), which shows that C800 has much bigger induced current than those of C700 and C900. It can be

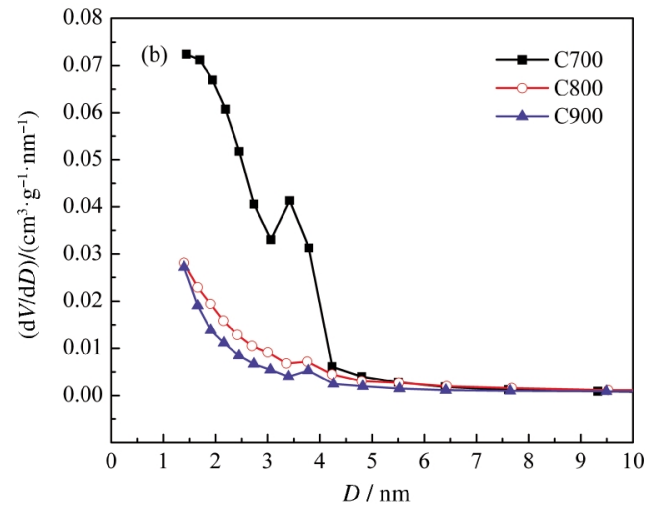

Fig.2 $\mathrm{N}_{2}$ adsorption isotherms (a) and pore size distributions (b) of the samples The pore size distribution is calculated using adsorption branch by the BJH method. 

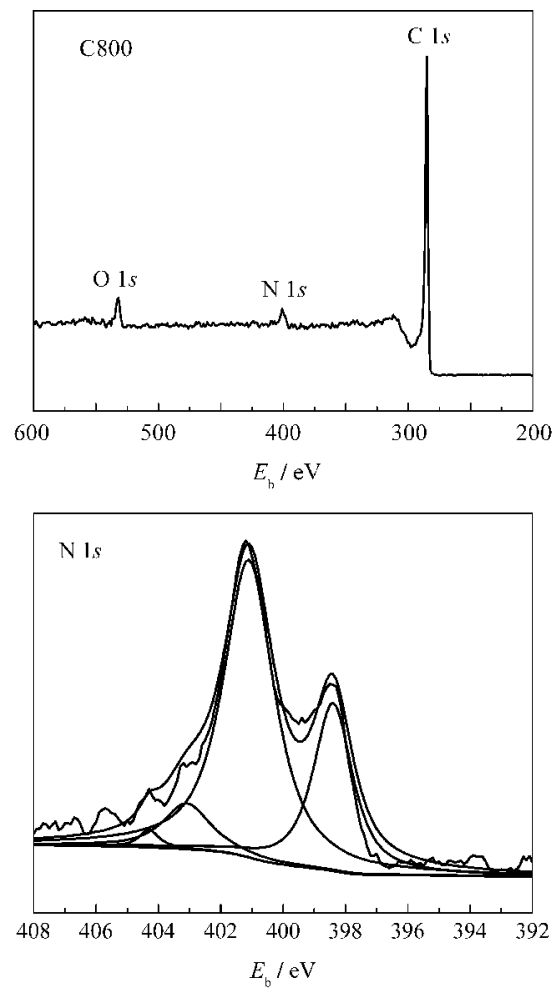
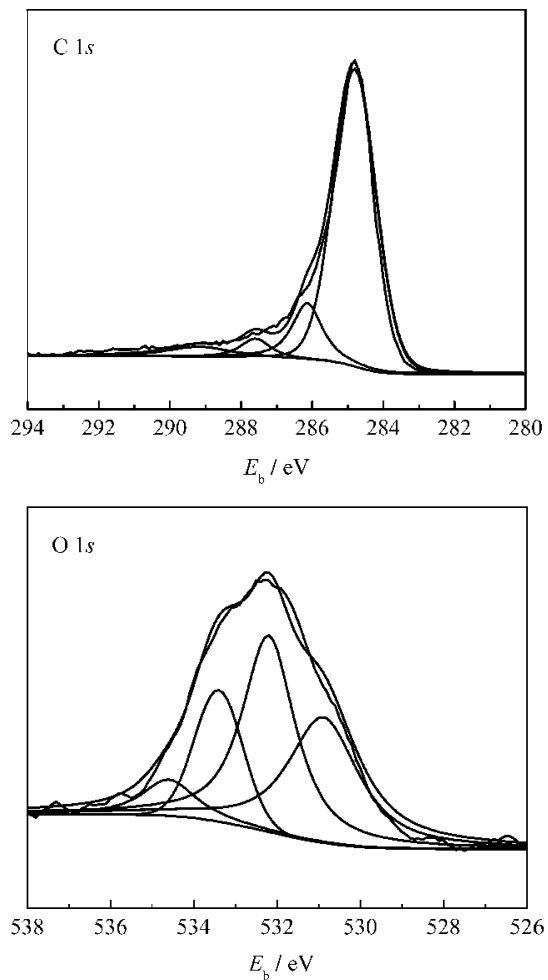

Fig.3 X-ray photoelectron spectra of C800

observed that C800 presents a quasi-rectangular voltammogram shape. The inner integrated area of CV curve of samples stands for the power density. The slope of $E / i$, indicated by the dotted box in Fig.4(a), stands for equivalent series resistance (ESR). In Fig.4(a), C800 has the biggest inner integrated area and the least slope of $E / i$, indicating $\mathrm{C} 800$ has the biggest power density and the smallest ESR. These indicate that C800 can be an excellent candidate as electrode material for supercapacitor. Moreover, the effect of voltage scan rates on the capacitive behavior of C800 was also investigated. Fig.4(b) presents the CV curves for $\mathrm{C} 800$ at different scan rates. As the scan rate increases, the $\mathrm{CV}$ curves become gradually depressed but still maintained a quasirectangular shape. It indicates that the C800 electrode would be suitable for quick charge-discharge operations.

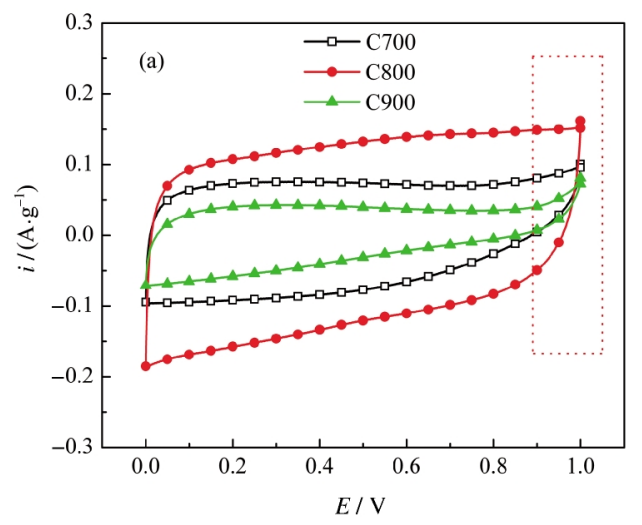

Table 2 shows elemental analyses of the samples, nitrogen contents in C700, C800, and C900 are 9.365\%, 4.805\%, and 2.906\%, respectively. It indicates that the nitrogen content in the sample decreases with increase of carbonization temperatures. Table 1 shows specific capacitance values of all samples at a current density of $0.5 \mathrm{~A} \cdot \mathrm{g}^{-1}$, and $\mathrm{C} 800$ exhibits the highest specific capacitance in all samples. Compared to $\mathrm{C} 700$, the specific surface area and pore volume of $\mathrm{C} 800$ are higher than that of $\mathrm{C} 700$ (Table 1), so C800 has higher double layer capacitance than that of $\mathrm{C} 700$; although the nitrogen content of $\mathrm{C} 800$ is lower than that of $\mathrm{C} 700$, the oxygen content of $\mathrm{C} 800$ is higher than that of C700 (Table 2), the influence of oxygen on pseudocapacitance may be stronger than that of nitrogen on pseudocapacitance ${ }^{[26]}$, so the specific capacitance of $\mathrm{C} 800$ is higher than that of $\mathrm{C} 700$.

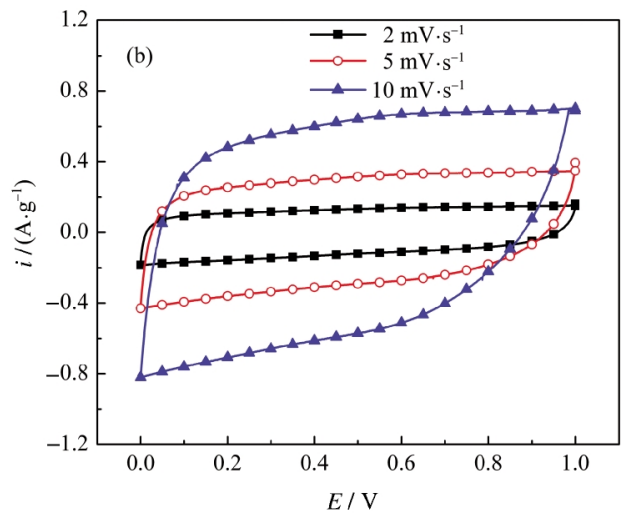

Fig.4 Cyclic voltammograms of as-prepared samples in $6 \mathrm{~mol} \cdot \mathrm{L}^{-1} \mathrm{KOH}$ electrolyte $i$ : current density; (a) $\mathrm{C} 700, \mathrm{C} 800$, and $\mathrm{C} 900$ at a scan rate of $2 \mathrm{mV} \cdot \mathrm{s}^{-1}$, (b) $\mathrm{C} 800$ at different scan rates 
Table 2 Elemental analysis of the samples

\begin{tabular}{cccccc}
\hline \multirow{2}{*}{ Sample } & \multicolumn{5}{c}{$w(\%)$} \\
\cline { 2 - 6 } & $\mathrm{N}$ & $\mathrm{C}$ & $\mathrm{S}$ & $\mathrm{H}$ & $\mathrm{O}$ \\
\hline $\mathrm{C} 700$ & 9.365 & 77.68 & 0.216 & 1.571 & 11.17 \\
$\mathrm{C} 800$ & 4.805 & 81.01 & 0.213 & 1.536 & 12.44 \\
$\mathrm{C} 900$ & 2.906 & 85.35 & 0.210 & 1.078 & 11.46 \\
\hline
\end{tabular}

Compared to $\mathrm{C} 900$, although the specific surface area of C800 is a little lower than that of $\mathrm{C} 900$, the nitrogen content of $\mathrm{C} 900$ is much lower than that of $\mathrm{C} 800$ and the oxygen content of C900 is lower, the contribution of pseudo-capacitance of $\mathrm{C} 900$ is much smaller than that of $\mathrm{C} 800$, so the specific capacitance of C800 is higher than that of $\mathrm{C} 900$.

The plots of obtained capacitance values of all samples $v s$ discharge current densities are displayed in Fig.5. The specific capacitance of all samples drop quickly as the current increases, and the reason may be that at the low currents, the ions have enough time to diffuse into the inner surfaces of carbon materials, while at the high currents the ions can only partially penetrate into the inner surfaces. The C800 shows more specific capacitance at all the current densities than those of C700 and C900, which is attributed to the high specific surface area and the proper proportion of heteroatoms of C800.

EIS is a powerful technique for investigating the capacitive behavior of supercapacitors. Typical Nyquist plots of the samples are shown in Fig.6. Each plot is composed of a very small

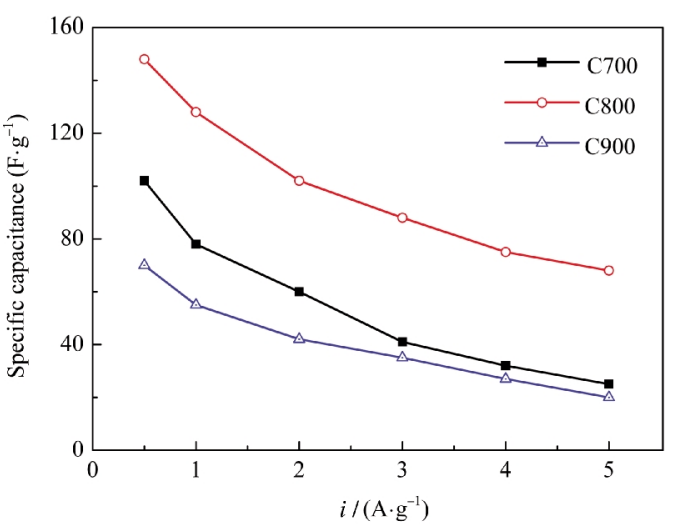

Fig.5 Comparison of capacitance decay with increasing discharge current densities for all samples

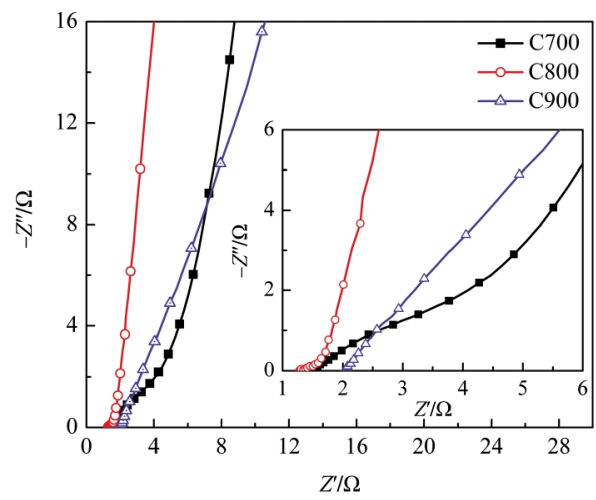

Fig.6 Nyquist plots of C700, C800, and C900 Potential is $5 \mathrm{mV}$. Inset: enlarged high-frequency regions of Nyquist plots semicircle in the high-frequency region and a straight line in the low-frequency region. At high frequency, the intercept at the real axis is the ESR. C800 electrode shows the smallest ESR, suggesting C800 electrode has the highest electronic conductivity, which is in good agreement with CV results. At low frequency, the straight line part of C800 carbon is more close to imaginary axis, suggesting $\mathrm{C} 800$ has an ideal capacitive behavior.

\section{Conclusions}

Novel carbon materials containing heteroatoms were prepared by carbonizing polyaniline at different temperatures and their electrochemical properties for supercapacitors were investigated. The results show that $\mathrm{C} 800$ has good electrochemical properties. Compared to activated carbon $\left(3500 \mathrm{~m}^{2} \cdot \mathrm{g}^{-1}\right)$, C800 has low specific surface area $\left(325 \mathrm{~m}^{2} \cdot \mathrm{g}^{-1}\right)$, but the specific capacitance value is as high as $153 \mathrm{~F} \cdot \mathrm{g}^{-1}$ at a current density of $0.5 \mathrm{~A} \cdot \mathrm{g}^{-1}$. The high specific capacitance of the carbon is believed to be associated with its proper proportion of heteroatoms (nitrogen and oxygen) that can provide the most pseudo-capacitance. These suggest that C800 can be used as an candidate electrode material for supercapacitors. Furthermore, there is still much room to further improve the performances of the carbon material by activating or preparing composites.

\section{References}

1 Conway, B. E. Electrochemical supercapacitors: scientific fundamentals and technological applications. New York: Kluwer Academic/Plenum Publishers, 1999

2 Huang, J. S.; Sumpter, B. G.; Meunier, V. Chem. Eur. J., 2008, 14: 6614

3 Zeng, W. W.; Huang, K. L.; Yang, Y. P.; Liu, S. Q.; Liu, R. S. Acta Phys. -Chim. Sin., 2008, 24(2): 263 [曾雯雯, 黄可龙, 杨幼平, 刘素琴, 刘人生. 物理化学学报, 2008, 24(2): 263]

4 Ye, X. G.; Zhang, X. G.; Mi, H. Y.; Yang, S. D. Acta Phys. -Chim. Sin., 2008, 24(6): 1105 [叶向果, 张校刚, 米红宇, 杨苏东. 物理 化学学报, 2008, 24(6): 1105]

5 Donne, S. W.; Hollenkamp, A. F.; Jones, B. C. J. Power Sources, 2010, 195: 367

6 Chen, L.; Zhang, X. G.; Yuan, C. Z.; Chen, S. Y. Acta Phys. -Chim. Sin., 2009, 25(2): 304 [陈 黎, 张校刚, 原长洲, 陈胜尧. 物理 化学学报, 2009, 25(2): 304]

7 Liu, E. H.; Li, W.; Li, J.; Meng, X. Y.; Ding, R.; Tan, S. T. Mater. Res. Bull., 2009, 44: 1122

8 Du, B.; Jiang, Q.; Zhao, X. F.; Lin, S. Z.; Mu, P. S.; Zhao, Y. Acta Phys. -Chim. Sin., 2009, 25(3): 513 [杜 冰, 江 奇, 赵晓峰, 林孙忠, 幕佩珊, 赵 勇. 物理化学学报, 2009, 25(3): 513]

9 Jiang, Q.; Zhang, Q.; Du, B.; Zhao, X. F.; Zhao, Y. Acta Phys. Chim. Sin., 2008, 24(9): 1719 [江 奇, 张 倩, 杜 冰, 赵晓 峰, 赵 勇.物理化学学报, 2008, 24(9): 1719]

10 Lü, X. M.; Wu, Q. F.; Mi, H. Y.; Zhang, X. G. Acta Phys. -Chim. Sin., 2007, 23(6): 820 [吕新美, 吴全富, 米红宇, 张校刚. 物理 化学学报, 2007, 23(6): 820] 
11 Sun, W.; Chen, X. Y. J. Power Sources, 2009, 193: 924

12 Park, B. O.; Lokhande, C. D.; Park, H. S.; Jung, K. D.; Joo, O. S. J. Power Sources, 2004, 134: 148

13 Dhawale, D. S.; Dubal, D. P.; Jamadade, V. S.; Salunkhe, R. R.; Lokhande, C. D. Synth. Met., 2010, 160: 519

14 Tian, Y. M.; Song, Y.; Tang, Z. H.; Guo, Q. G.; Liu, L. J. Power Sources, 2008, 184: 675

15 Wen, Z. B.; Qu, Q. T.; Gao, Q.; Zheng, X. W.; Hu, Z. H.; Wu, Y. P.; Liu, Y. F.; Wang, X. J. Electrochem. Commun., 2009, 11: 715

16 Gadiou, R.; Didion, A.; Gearba, R. I.; Ivanov, D. A.; Czekaj, I.; Kötz, R.; Vix-Guterl, C. J. Phys. Chem. Sol., 2008, 69: 1808

17 He, X. J.; Lei, J. W.; Geng, Y. J.; Zhang, X. Y.; Wu, M. B.; Zheng, M. D. J. Phys. Chem. Sol., 2009, 70: 738

18 Trchová, M.; Matějka, P.; Brodinova, J.; Kalendová, A.; Prokeš, J.; Stejskal, J. Polym. Degrad. Stabil., 2006, 91: 114

19 Langer, J. J.; Golczak, S. Polym. Degrad. Stabil., 2007, 92: 330
20 Biniak, S.; Szymański, G.; Siedlewski, J.; Swiatkowski, A. Carbon, 1997, 35: 1799

21 Zielke, U.; Hüttinger, K. J.; Hoffman, W. P. Carbon, 1996, 34: 983

22 Figueiredo, J. L.; Pereira, M. F. R.; Freitas, M. M. A.; Órfão, J. J. M. Carbon, 1999, 37: 1379

23 Kapteijn, F.; Moulijn, J. A.; Matzner, S.; Boehm, H. P. Carbon, 1999, 37: 1143

24 Kim, Y. J.; Abe, Y.; Yanagiura, T.; Park, K. C.; Shimizu, M.; Iwazaki, T.; Nakagawa, S.; Endo, M.; Dresselhaus, M. S. Carbon, 2007, 45: 2116

25 Jurewicz, K.; Babel, K.; Ziolkowski, A.; Wachowska, H. Electrochim. Acta, 2003, 48: 1491

26 Jurewicz, K.; Pietrzak, R.; Nowicki, P.; Wachowsk, H. Electrochim. Acta, 2008, 53: 5469 